\title{
QALBU DALAM KAJIAN PSIKOLOGI ISLAM
}

\author{
Anri Saputra, Mela Rospita, Vivik Shofiah \\ Fakultas Psikologi UIN Sultan Syarif Kasim Riau \\ andri.syah92@gmail.com, mela.rospita@yahoo.com, vivik.shofiah@uin-suska.ac.id
}

\begin{abstract}
In the treasures of Islamic psychology, heart is one of the central terms discussed in depth. Because according to the study of Islamic psychology, heart is one of the structures of human personality. Even the heart is a determinant of good or bad behavior of a person. The heart is always the most important substance in human beings, the conversation that is used to judge someone is always related to heart, not only behavior but from individual faith tends to focus on heart. If one's heart is good so good is the faith. But if the qalbunya is bad then the faith will be bad. This study is a literature study. This study is expected to be able to add insight and knowledge about Qalbu which is one of the studies of Islamic Psychology.
\end{abstract}

Keywords : Qalbu, Psychology, Islam

\section{Pendahuluan}

Qalbu merupakan komponen dalam kejiwaan yang dianugerahkan Allah SWT kepada manusia.Qalbu menjadi penentu tingkah laku manusia.Rasulullah SAW menegas kan bahwa baik buruknya seseorang tergantung kepada keputusan qalbunya. Dalam sebuah hadits yang diriwayatkan oleh Imam Bukhori dan muslim rasulullah SAW bersabda yang artinya: "Sesungguhnya di dalam tubuh manusia ada segumpal daging. Jika segumpal daging tersebut baik maka akan baik pulalah seluruh tubuhnya, jika segumpal daging tersebut rusak maka akan rusak pulalah seluruh tubuhnya, ketahuilah segumpal daging tersebut adalah Qalbu. Dari hadits tersebut dapat diketahui bahwa penggerak dan penentu perbuatan manusia adalah Qalbu. Jika qalbunya baik maka arah perilakunya pun akan baik, namun jika Qalbunya buruk maka perilaku yang timbulpun akan buruk. Jika dalam bahasa Indonesia Qalbu diartikan sebagai "Jantung" namun didalam bahasa Arab Qalbu diartikan sebagai hati, dan akal. Singkatnya Qalbu adalah bagian organ segala sesuatu yang meme nuhi syarat untuk mempertanggung jawabkan perilaku manusia. Dengan demikian Qalbu tidak akan luput dari pengadilan akhirat, yang dituntut untuk mempertanggungjawabkan semua perilaku yang dilakukannya selama di dunia.

Ali dan Zuhdi (1973)memaknakan Qalbu dengan mengubah, membalikkan,dan mengganti.Semen tara Imam Al-Ghazali berpandangan bahwa Qalbu merupakan daging yang terletak di sebelah kiri dada dan 
berbentuk memanjang bundar (AlGhazali 1998).

Al-Quran menggunakan istilah hati dalam berbagai pengertian yang kesemuanya menunjukkan pada sentralitas hati dalam diri manusia. Dengan demikian, hati merupakan bagian dari spritual manusia. Sama halnya dengan Qalbu yang keberadaanya hanya dapat dirasakan, tanpa dapat dilihat dan diraba.

Qalbu selalu menjadi subtansi yang paling penting dalam diri manusia, perbincangan yang dijadikan untuk menilai seseorang selalu berkaitan dengan Qalbu atau disebut dengan hati, bukan hanya tingkah laku namun dari keimanan individupun cenderung fokus dengan Qalbu, apabila Qalbu seseorang tersebut baik maka baik pulalah imannya. Seperti do'a yang selalu dipanjatkan oleh umat muslim: "Wahai zat yang membolak-bolakkan hati, teguhkanlah hati kami diatas agamamu, wahai zat yang membolak-balikkan hati tuntunlah hati kami teguh di atas ketaatan kepadaMu."

Menurut Rasulullah dalam salah satu hadistnya, syarat utama masuk surga ialah keadaan hati yang bersih, yang tidak dikotori dengan berbagai macam penyakit hati. Dengan demikian bisa dikatakakan manusia yang mempunyai hati, tetapi tidak dipakai untuk memahami, maka hatinya tergolong hati yang lalai. Sebaik-baiknya hati adalah hati yang mampu mendorong dan menerima agama untuk diamalkan, hati yang seperti ini disebut dengan hati yang hidup (Qalbul hayyah), karena masih menampakkan fungsi dari hati yang sesungguhnya, yaitu memahami dan menerima kebenaran. Sementara hati yang mati (Qalbul Mayyitah) tidak akan mampu memahami dan menerima kebenaran. Karena sudah tertrutup oleh penyakit yang disebabkan banyaknya dosa yang telah dilakukan.

Qalbu yang didalamnya ada iman akan mendorong manusia untuk berbuat baik dengan tujuan mendapatkan ridho Allah, dan qalbu yang didalamnya ada ilmu akan mendorong perilaku manusia supaya berperilaku sesuai dengan aturan agama. Sementara Qalbu yang didalamnya tidak ada iman dan ilmu akan tersesat, tidak tahu arah dan tujuan, sehingga ia terjebak dalam gelimang dosa dan maksiat, yang membuatnya jauh dari agama.

Rumusan permasalahan dalam kajian ini adalah Bagaimanakah psikologi islam mengkaji Qalbu?

Kajian ini diharapkan dapat menambah wawasan dan khasanah ilmu pengetahuan mengenai Qalbu yang menjadi salah satu kajian psikologi Islam.

\section{METODE PENELITIAN}

Kajian ini merupakan penelitian studi pustaka. Menurut Wibirama (2015) kajian studi pustaka merupakan karya tulis ilmiah yang memuat pembahasan penelitian terdahulu dan referensi ilmiah. Penelitian ini fokus pada kajian-kajian 
psikologi islam dengan mengambil referensi ilmiah yang berkaitan dengan kajian psikologi Islam.

Menurut Sugiyono (2012), studi kepustakaan berkaitan dengan kajian teoritis dan referensi lain yang berkaitan dengan nilai, budaya dan norma yang berkembang pada situasi sosial yang diteliti, selain itu studi kepustakaan sangat penting dalam melakukan penelitian, hal ini dikarenakan penelitian tidak akan lepas dari literatur-literatur IImiah.

\section{PEMBAHASAN}

Ada beberapa versi dalam kajian struktur kepribadian manusia dalam perspektif psikologi islam. AlGhazali dalam Bastaman (2005) membagi struktur kepribadian manusia menjadi empat, yaitu qalbu, roh, nafs, dan akal.Sementara itu, AlGhazali dalam versi Mujib (2017) membagi tiga, yaitu hawa nafs, aql, dan qalb.Ketiganya disebut nafs, kemudian dibagi menjadi dua, yaitu jasad dan roh.Mubarok (2005) membagi menjadi empat juga, yaitu nafs, qalb, aql, dan basyirah.Sukanto (1985) membaginya menjadi empat sistem, yaitu qalb (angan-angan), fuad (perasaan/hati nurani/ulu hati), ego (aku sebagai pelaksana dari kepribadian) dan tingkah laku (wujud gerakan).

Dari sekian banyak pendapat maka dapat disimpulkan bahwa secara garis besar struktur kepribadian manusia dibagi menjadi tiga, yaitu qalb (struktur terdalam pada manusia dikendalikan oleh roh, rekan kerjanya adalah wahyu dan ilham), jism (struktur terluar pada manusia dikendalikan oleh fisik atau tubuh, rekan kerjanya adalah hawa nafsu dan nafsu syahwat) dan nafs (unsur yang menjadi perpaduan Qalbu dan Jism dikendalikan oleh rasio qalbani dan rasio nafsani, rekan kerjanya adalah qalbu dan balatentaranya. Serta panca indra dan seluruh anggota tubuh.

\section{Konsep Qalbu Dalam Psikologi Islam}

Apa sebenarnya qalbu itu? Kata Qalbu dengan segala bentuknya (tunggal maupun jamak diungkap dalam Al-Qur'an sebanyak 132 kali dalam 126 surat). Jumlah ini tidak termasuk kata kerjanya (fiil) dan juga tidak termasuk sinonimnya seperti :Fuad dan Shodari (Mukhlis dan Lestari, 2011).

Dalam bahasa arab, istilah qalbu digunakan untuk menyebut banyak hal seperti : Jantung, hati, isi, akal, semangat, keberanian, bagian dalam, bagian tengah untuk menyebut sesuatu yang murni.

Dalam Al-Qur'an kata Qalbu digunakan untuk menyebutkan:

\section{Hati Manusia}

Sesuai dengan firman Allah SWT yang artinya: "Dan janganlah kamu mengikuti apa yang kamu tidak mempunyai pengetahuan tentangnya . Sesungguhnya pendengaran, penglihatan dan hati, semua itu akan dimintai pertanggungjawabannya" (Q.S. AlIsra': 36). Dan firman Allah SWT 
dalam surat As-Syu'ara ayat 89 : "Kecuali orang-orang yang menghadap Allah dengan hati yang bersih.

2. Akal Manusia

Sesuai dengan firman Allah SWT: "Maka apakah mereka tidak berjalan dimuka bumi, lalu mereka mempunyai hati yang dengan itu mereka dapat memahami, atau mempunyai telinga yang dengan itu mereka dapat mendengar? Karena sesungguhnya bukanlah mata itu yang buta, tetapi yang buta ialah hati yang ada di dalam dada" (Q.S. Al-Hajj :46).

3. Ruh

Sesuai dengan firman Allah SWT: "Yaitu) ketika mereka datang kepadamu dari atas dan dari bawahmu, dan ketika tidak tetap lagi penglihatan (mu) dan hatimu naik menyesak sampai ke tenggorokan, dan kamu menyangka terhadap Allah dengan bermacam-macam purbasangka" (Q.S. Al-Ahzab : 10).

Qalbu menurut Ibnu Araby dalam Corbin (1998) adalah "the organ which produce true knowledge, comprehensive intuition, the gnosis (ma'rifah) of God and the divine myteries, in short, the organ of everything conneted by the term "esoteric science"('Ilm bathin)". Yang berarti Qalbu adalah suatu organ tubuh yang menghasilkan pengetahuan yang benar, intuisi yang menyuluruh, mengenal Allah SWT,

dan misteri ketuhanan.Singkatnya Qalbu adalah bagian organ segala sesuatu yang memenuhi syarat untuk mengetahui ilmu ghaib, dalam istilah Faridi (1993) Qalbu disebut intelligent self, yang berarti Qalbu adalah tempat pertanggungjawaban manusia "qalb is the seat of human responsibility".

Sifat Qalbu yang seperti inilah yang kemudian disebut rasio qalbani yang ada dalam nafs, sebagai penjelmaan selfish self, yaitu tempat mengaktualisasikan segala potensi yang ada pada Qalbu berupa kekuatan rohani sehingga berdampak pada tindakan atau perilaku.Gawin (2002) mengatakan bahwa tindakan fisik secara kreatif adalah untuk mengekspresikan spirit (rohani).

Dengan demikian, Qalbu adalah bagian spiritual manusia.la ada, tapi keberadaannya hanya dapat dirasakan, seperti tiupan angin yang semilir terasa menyejukkan. Untuk dapat merasakannya dibutuhkan seni tersendiri, yaitu menghaluskan segala gerak dan daya, baik dengan berzikir, i'tikaf, muhasabah, shalat atau dapat juga melalui meditasi dengan memusatkan perhatian pada sentuhan-sentuhan kasih sayang Tuhan. Sebagaimana halnya bagian fisik, Qalbu juga memiliki kebutuhan, antara lain: ketenangan, kedamaian, ketenteraman, keindahan dan cinta. Gerakan Qalbu amat halus, lembut tapi memiliki kekuatan yang tak terbendung oleh apapun.

\section{Karakteristik Qalbu}

Dalam konteks nafsmanusia, Qalbu bukanlah sepotong organ tubuh, tetapi sebagaimana akal dan 
basyirah merupakan elemen atau sub sistem dalam sistem nafsani yang bersifat ruhani. Dalam bahasa Indonesia, kata qalbu yang digunakan untuk menyebut hati, baik dalam arti fisik (liver) maupun secara maknawi. Dalam bahasa arab, Qalbu berarti "bolak-balik". Pengertian Qalbu ini menjadi karakteristik dari sifat Qalbu itu sendiri yaitu tidak konsisten atau bolak-balik.

Eksistensi karakteristik sifat Qalbu yang bolak-balik atau tidak konsisten mengindikasikan dua hal :Pertama, adanya getaran (vibrasi) yang menggambarkan kehidupan. Di dalam gerakan Qalbu itu denyutan nadi dan sirkulasi darah dipersatukan, diamnya gerakan Qalbu adalah kematian, sementara getaran Qalbu merupakan kehidupan.

Kedua, menggambarkan keimanan manusia yang naik turun. Karena iman itu sifatnya bisa bertambah dan bisa berkurang, iman akan bertambah kuat ketika manusia melakukan perbuatan baik, dan iman akan melemah ketika manusia berbuat jahat (maksiat), sementara iman itu terletak di dalam Qalbu.

\section{Bagian-Bagian Qalbu}

Menurut Baharuddin (2007) jika dilihat dari kondisi atau situasinya, maka qalbu dibagi menjadi tiga bagian :Pertama, Qalbu yang baik yang dianggap hidup (Qalbul Hayyah).Dalam kondisi ini Qalbu berada dalam keadaan sehat, bening, bersih dan baik. Qalbu yang baik ini akan menghasilan iman yang berupa : taqwa, khusyu', taubat, sabar, dan lain-lain. Qalbu dalam kondisi yang baik inilah yang dapat menerima kebenaran.

Kedua, Qalbu yang tidak baik yang dianggap mati (Qalbul Mayyitah).Dalam kondisi ini Qalbu berada dalam keadaan berpaling, sesat, buta, dan kasar.Qalbu dalam kondisi yang tidak baik ini tidak dapat menerima kebenaran.Ketiga, Qalbu antara baik dan buruk yang dianggap antara hidup dan mati (baina alhayyah wa al-mayyitah).Qalbu ini tetap hidup tapi berpenyakit.Dalam kondisi ini Qalbu berada dalam kemunafikan dan keragu-raguan. Menurut Ibnu Taimiyyah, penyakit Qalbu menyebabkan manusia akan membenci hal-hal yang bermanfaat bagi diri (nafs)nya dan menyukai halhal yang merusak dirinya.

\section{Fungsi Qalbu}

Fungsi utama dari qalbu adalah sebagai alat untuk memahami realitas dan nilai-nilai. Hal ini sesuai dengan firman Allah SWT :"Maka apakah mereka tidak berjalan dimuka bumi, lalu mereka mempunyai hati yang dengan itu mereka dapat memahami, atau mempunyai telinga yang dengan itu mereka dapat mendengar? Karena sesungguhnya bukanlah mata itu yang buta, tetapi yang buta ialah hati yang ada di dalam dada" (Q.S. Al-Haij :46).Dalam ayat ini qalbu diberikan fungsi untuk melihat hal-hal yang ada di sekelilingnya, dengan memahami realitas yang ada, dengan tujuan 
untuk mencari kebenaran ayat-ayat Allah melalui alam yang diciptakannya.Sehingga Qalbu memiliki pandangan yang lebih tajam daripada pandangan mata, oleh karena itu Qalbu yang tidak bisa melihat kebenaran dikatakan Qalbu yang buta.Bahkan ketika seseorang tidak bisa melihat kebenaran sebenarnya bukan karena kebutaan matanya, tetapi karena kebutaan hatinya (Qalbunya).

Dan firman Allah SWT dalam surat Al-A'raf ayat 179 :"Dan sesungguhnya kami jadikan untuk (isi neraka jahannam) kebanyakan dari jin dan manusia, mereka mempunyai hati, tetapi tidak dipergunakan untuk memahai (ayat-ayat Allah) dan mereka mempunyai mata (tetapi) tidak dipergunakan untuk melihat (tanda-tanda kekuasaan Allah), dan mereka mempunyai telinga (tetapi) tidak dipergunakan untuk mendengar (ayat-ayat Allah). Mereka itu seperti binatang ternak, bahkan mereka lebih sesat, mereka itulah orang-orang yang lalai.

Qalbu mempunyai fungsi yang sama dengan Akal manusia. Berdasarkan fungsi utama ini maka Qalbu secara sadar dapat memutuskan sesuatu atau dapat melakukan sesuatu.Dari fungsi utama qalbu ini maka perbuatan yang dipertanggungjawabkan manusia kepada tuhan adalah perbuatan yang disadari oleh Qalbunya. Sehingga ketika seseorang melakukan kebaikan tanpa menyertakan Qalbunya maka kebaikan tersebut tidak akan dianggap sebagai ibadah, dan sebalikya, kejahatan yang tidak disadari oleh Qalbunya tidak akan dihitung sebagai dosa.

Dari penjelasan di atas dapat diketahui bahwa fungsi Qalbu selain mempunyai daya emosi juga mempunyai daya kognisi.Namun daya emosi Qalbu lebih banyak diungkap ketimbang daya kognisinya. Daya Qalbu ada yang positif seperti : cinta, senang, riang, percaya, tulus dan sebagainya. Sementara daya Qalbu yang negatif adalah seperti : benci, sedih, ingkar, mendua dan sebagainya.

Menurut Ma'an Ziyadah, Qalbu berfungsi untuk mengungkap hal-hal doktrinis, memperoleh hidayah, ketaqwaan, rahmah, serta mampu memikirkan dan merenungkan sesuatu. Dengan konsep ini maka daya Qalbu mampu menghantarkan manusia pada tingkat spritualitas, keagamaan, dan ketuhanan.

\section{POTENSI QALBU MENURUT AL- QUR'AN}

Selain memiliki beberapa fungsi, qalbu juga memiliki beberap potensi yaitu:

1. Melakukan Sesuatu Secara Sengaja

Sesuai dengan firman Allah SWT: "Pergilah mereka (anak angkat itu) dengan (memama) nama bapak-bapak mereka; itulah yang adil disisi Allah, dan jika kamu tidak mengetahui bapak mereka, maka (panggillah mereka sebagai) saudara-saudaramu 
seagama dan maulanamaulanamu (hamba sahaya yang sudah di merdekakan). Dan tidak ada dosa atasmu jka kamu khilaf tentang itu, tetapi (yang ada dosanya) apa yang disengaja oleh hatimu. Allah maha pengampun lagi maha penyayang "(Q.S. A/Ahzab : 5).

Dalam ayat ini ditegaskan bahwa Qalbu memiliki potensi untuk memutuskan sesuatu, Qalbu memiliki otoritas untuk menentukan keinginannya, Qalbu juga bisa menimbang mana yang baik dan mana yang buruk, sehingga apapun yang yang diputuskan oleh Qalbu dapat bernilai ibadah disisi Allah. Jika yang diputuskan adalah kebaikan (ibadah) maka akan dihitung sebagai pahala, dan jika yang diputuskan adalah keburukan (maksiat) akan dihitung sebagai dosa. Bahkan dalam ayat ini dijelaskan perbuatan maksiat yang dilakukan tanpa keputusan dari hati (karena khilaf) tidak akan dihitung sebagai dosa.

2. Merasa Kesal dan Gembira

Sesuai dengan firman Allah SWT: "Dan apabila yang disebut hanya nama Allah, kesal sekali hati orang-orang yang tidak beriman kepada kehidupan akhirat. Namun apabila nama-nama sembahan selain Allah yang disebut, tiba-tiba mereka menjadi gembira" (Q.S. Az- Zumar: 45).

Dalam ayat ini digambarkan bahwa rasa kesal dan gembira itusaling kontradiktif, jika seseorang merasa kesal maka rasa gembiranya akan hilang, dan sebaliknya jika seseorang merasa gembira maka rasa kesalnya pun akan hilang.

3. Bisa Berpaling

Sifat dari qalbu yang sesungguhnya adalah selalu berbolak-balik, tidak konsisten, dan selalu berubah-ubah, karena Qalbu akan tetap ketika ia memiliki keyakinan, dan akan berpaling ketika ia merasa ragu-ragu. Allah SWT berfirman: "Sesungguhnya Allah telah menerima taubat Nabi, orang-orang muhajiirn, dan orangorang ansor, yang mengikuti nabi pada masa-masa sulit. Setelah hati dari segolongan mereka hampir berpaling, kemudian Allah menerima taubat mereka. Sesungguhnya Allah maha pengasih maha penyayang kepada mereka" Q.S. At-Taubah ; 117).

4. Berprasangka

Prasangka merupakan potensi Qalbu, prasangka terjadi sebelum Qalbu memutuskan, persangka ini bisa baik dan bisa juga buruk, bahkan prasangka bisa membawa kepada kebahagiaan atau kebinasaan. Firman Allah SWT: "Bahkan (semula) kamu menyangka bahwa rasul dan orang-orang mukmin sekali-kali tidak akan kembali lagi kepada keluarga mereka selama-lamanya, dan dijadikan terasa indah yang demikian itu di dalam hatimu, dan kamu telah berprasangka dengan prasangka yang buruk, karena itu kamu menjadi kaum yang binasa" 
Anri Saputra, Mela Rospita, Vivik Shofiah : Qalbu Dalam Kajian Psikologi Islam DOI:10.24014/af.v18.i1.7154

(Q.S. Al-Fath: 12).

5. Mengingkari

Sesuai dengan firman Allah SWT :"Tuhan kamu adalah tuhan yang maha esa, maka orang yang tidak beriman kepada Akhirat, hati mereka mengingkari (keesaan Allah), dan mereka adalah orangorang yang sombong" (Q.S. AnNahl : 22).

Selain menerima, hati juga berpotensi untuk mengingkari.Dalam hal menerima dan mengingkari ini sangat erat kaitannya dengan perkara iman dan kebenaran.Sehingga Allah lah yang paling berperan dalam menentukan apakah hati kita menerima atau mengingkari, karena kita tidak bisa memaksakan hati kita untuk menerima atau mengingkari kebenaran, bahkan kadang fikiran kita menerima tapi hati kita mengingkari.

6. Dapat Diuji

Qalbu adalah sasaran ujian, sehingga Qalbu selalu dituntut untuk sabar.Sabar dalam menghadapi musibah, sabar dalam meninggalkan maksiat, dan sabar dalam melaksanakan perintah Allah. Sehingga orang yang bisa melewati ujian dengan kesabaran tersebut akan mendapat predikat taqwa disisi Allah. Firman Allah SWT :"sesungguhnya orang-orang yang merendahkan suaranya di sisi rasulullah, mereka itulah orang-orang yang telah diuji hatinya oleh Allah untuk bertaqwa. Mereka akan memperoleh ampunan dan pahala yang besar"
(Q.S. Al-Hujurat: 3).

7. Dapat Ditundukkan

Sesuai dengan firman Allah SWT : "Dan agar orang-orang yang telah diberi ilmu meyakini bahwa (Al-Qur'an) itu benar dari Tuhanmu lalu mereka beriman dan hati mereka tunduk kepadanya. Dan sungguh, Allah pemberi petunjuk bagi orang-orang yang beriman kepada jalan yang lurus" (Q.S. AlHajj: 54).

Dalam ayat ini dijelaskan bahwa hati dapat ditundukkan dengan keimanan. Jika hati seseorang sudah dipenuhi dengan keimanan, maka hatinya akan selalu tunduk kepada Allah. Dan untuk memperoleh keimanan tersebut dibutuhkan ilmu pengetahuan, sehingga dengan ilmu pengetahuan tersebut dapat mengantarkan manusia untuk meyakini Al-Qur'an sebagai wahyu yang diturunkan Allah SWT, yang dapat mengantarkan manusia untuk memperoleh keimanan.

8. Bisa Ditutup Rapat

"Allah telah mengunci hati dan pendengaran mereka, penglihatan mereka telah tertutup, dan mereka akan mendapat azab yang berat" (Q.S. Al-Baqarah: 7).

Hati bisa tertutup karena banyaknya dosa, sehingga hati tidak bisa lagi menerima kebenaran.Kecuali hati yang diberikan hidayah oleh Allah SWT.

\section{Sifat Positif Qalbu Menurut Al- Qur'an}

Disamping mempunyai fungsi 
dan potensi, qalbu juga memiliki sifat positif. Diantara sifat positif itu antara lain adalah:

1. Bergetar Karena Iman

"Sesungguhnya orang-orang yang beriman adalah mereka yang apabila disebut nama Allah gemetar hatinya, dan apabila dibacakan ayat-ayatnya kepada mereka, bertambah (kuat) imannya dan hanya kepada tuhan mereka bertawakkal (Q.S. Al-Anfal: 2).

Maksud "disebut nama Allah" disini adalah menyebut sifat dan mengagungkan dan memuliakannya. Karena kuatnya iman, dan tingginya rasa cinta kepada Allah, ketika nama dan sifat Allah disebut maka hatinyapun bergetar.

2. Memiliki Ketenangan

Ketenangan hati dapat dirasakan karena buah dari iman dan ketakwaan kepada Allah, hati akan tenang ketika berzikir kepada Allah, dan hati juga akan tenang ketika ia dipenuhi rasa cinta kepada Allah. Allah SWT berfirman:

"Dialah yang telah menurunkan ketenangan ke dalam hati orangorang mukmin untuk menambah keimanan atas keimanan mereka (yang telah ada). Dan milik Allah lah bala tentara langit dan bumi, dan Allah maha mengetahui, maha bijaksana (Q.S. Al-Fath : 4).

Maksud "bala tentara langit dan bumi" dalam ayat ini adalah penolong yang dijadikan Allah untuk orang-orang mukmin seperti malaikat, hewan-hewan, angin topan, dan sebagainya.

3. Kasih Sayang

"Kemudian kami susulkan rasul-rasul kami mengikuti jejakjejak mereka, dan kami susulkan (pula) Isa putra Maryam; dan kami berikan Injil kepadanya dan kami jadikan rasa santun dan kasih sayang dalam hati orang-orang yang mengikutinya.Mereka mengada-adakan Rahbaniyyah padahal kami tidak mewajibkannya kepada mereka (yang kami wajibkan hanyalah) mencari ridha Allah, tetapi tidak mereka pelihara dengan semestinya. Maka kepada orang-orang yang beriman diantara mereka kami berikan pahalanya, dan banyak diantara mereka yang fasik" (Q.S. Al-Hadid :27). Kasih sayang yang diberikan Allah kepada hati manusia adalah suatu anugerah, karena dengan adanya kasih sayang manusia bisa hidup damai, manusia bisa membina rumah tangga dan memiliki keturunan, dan manusia juga bisa merasakan indahnya kasih sayang tuhan.

4. Kebaikan

Fitrah dari Qalbu itu sendiri adalah kebaikan, sehingga sudah seharusnya yang keluar dari hati adalah kebaikan juga. Namun terkadang ia menjadi kotor karena dosa dan maksiat yang dilakukan oleh manusia. Maka selama hati masih mempertahankan fitrah kebaikannya, ia akan tetap dianggap sebagai hati yang beriman, dan hati yang beriman akan mendapat pertolongan dari 
Allah, baik di dunia maupun di akhirat. Allah SWT berfirman:

"Wahai Nabi (Muhammad) katakanlah kepada tawanan perang yang ada di tanganmu, "Jika Allah mengetahui ada kebaikan di dalam hatimu, niscaya dia akan memberikan yang lebih baik dari apa yang telah diambil darimu dan dia akan mengampuni kamu". Allah maha pengampun, maha penyayang" (Q.S. Al-Anfal : 70).

5. Iman

"Dan ketahuilah bahwa
ditengah-tengah kamu ada
rasulullah. Kalau dia menurut
(kemauan) kamu dalam banyak
hal, pasti kamu akan mendapatkan kesusahan. Tetapi Allah menjadikan kamu cinta kepada keimanan, dan menjadikan iman itu indah dalam hatimu, serta menjadikan kamu benci kepada kekafiran, kefasikan, dan kedurhakaan. Mereka itulah orangorang yang mengikuti jalan yang Iurus" (Q.S. Al-Hujurat : 7).

Iman adalah hal yang paling berharga yang tersimpan di dalam Qalbu manusia.Karena iman adalah penentu seseorang bahagia atau celaka. Seseorang yang memiliki iman didalam hatinya walaupun hanya sebiji zarrah akan dimasukkan kedalam rahmat Allah di akhirat kelak, walaupun dia bergelimang dengan maksiat. Namun sebaliknya seseorang yang tidak memiliki iman dalam hatinya akan dimasukkan ke dalam neraka selama-lamanya, walaupun dia bergelimang dengan kebaikan.

Pembahasan tentang Iman ini dijelaskan juga dalam surat AlHujurat ayat 14: "Orang-orang arab badui itu berkata: "Kami telah beriman". Katakanlah (kepada mereka), kamu belum beriman, tetapi katakanlah, "kami telah tunduk (islam)", karena iman belum masuk ke dalam hatimu. Dan jika kamu taat kepada Allah dan Rasulnya, dia tidak akan mengurangi sedikitpun (pahala) amalmu. Sungguh, Allah maha pengampun, Maha penyayang".

\section{Sifat Negatif Qalbu Menurut Al- Qur'an}

Selain sifat positif, qalbu juga memiliki sifat negatif. Diantara sifat negatif itu antara lain adalah:

1. Penyakit Hati

"Dalam hati mereka ada penyakit, lalu Allah menambah penyakit itu; dan mereka mendapat azab yang pedih, karena mereka berdusta” (Q.S. Al-Baqarah : 10).

Maksud penyakit dalam ayat ini adalah penyakit hati, diantara penyakit hati itu ialah :ragu, tidak yakin akan kebenaran, munafik, dan tidak beriman. Pembahasan tentang penyakit hati ini dijelaskan juga dalam surat Al-Ahzab ayat 32:

"Wahai istri-istri Nabi! Kamu tidak seperti perempuanperempuan yang lain, jika kamu bertakwa, maka janganlah kamu tunduk (melemah lembutkan suara) dalam berbicara sehingga 
bangkit nafsu orang yang ada penyakit dalam hatinya, dan ucapkanlah perkataan yang baik".

Pengertian

"melemahlembutkan suara" disini adalah berbicara dengan sikap yang menimbulkan orang lain bertindak yang tidak baik terhadap mereka. Sementara pengertian dalam "hatinya" adalah orang yang mempunyai niat yang jahat dengan perempuan seperti melakukan zina.

2. Kedengkian

"Dan orang-orang yang datang sesudah mereka (Muhajirin dan Ansar), mereka berdo'a, "Ya Tuhan kami, ampunilah kami dan saudara-saudara kami yang telah beriman lebih dahulu dari kami, dan janganlah engkau tanamkan kedengkian dalam hati kami terhadap orang-orang yang beriman. Ya Tuhan kami, sungguh, engkau maha penyantun, maha penyayang" (Q.S. Al-Hasyr : 10).

Kedengkian ini termasuk penyakit hati yang berbahaya, karena selain membahayakan diri sendiri, kedengkian juga bisa membahayakan orang lain. Dan seseorang yang selalu diselimuti rasa dengki tidak akan memperoleh ketenangan dalam hidupnya.

3. Kesesatan

Allah menyelamatkan hati yang dia kehendaki, juga menyesatkan hati yang dia kehendaki.Namun ada juga hati yang condong kepada kesesatan, dikarenakan manusia selalu mencari-cari alasan dan kemudahan dari hukum Allah, dan mereka tidak menggunakan akal untuk mengambil pelajaran. Firman Allah SWT:

"Dialah yang menurunkan kitab (Al-Qur'an) kepadamu (Muhammad). Di antaranya ada ayat-ayat yang Muhkamat, itulah pokok-pokok kitab (Al-Qur'an) dan yang lain Mutasyabihat. Adapaun orang-orang yang dalam hatinyan condong kepada kesesatan, mereka mengikuti yang Mutasyabihat untuk mencari-cari fitnah dan mencari-cari takwilnya, padahal tidak ada yang mengetahui takwilnya kecuali Allah. Dan orang-orang yang ilmunya mendalam berkata, "kami beriman kepadanya (Al-Qur'an), semuanya dari sisi Tuhan kami", tidak ada yang dapat mengambil pelajaran kecuali orang yang berakal (Q.S. Ali-Imran : 7).

4. Penyesalan

"Hai orang-orang yang beriman! Janganlah kamu seperti orang-orang kafir yang mengatakan kepada saudaranya apabila mereka mengadakan perjalanan di bumi atau berperang. "Sekiranya mereka tetap bersama kita, tentulah mereka tidak mati dan tidak terbunuh."(Dengan perkataan) yang demikian itu, karena Allah hendak menimbulkan rasa penyesalan di hati mereka. Allah menghidupkan dan mematikan, dan Allah maha melihat apa yang kamu kerjakan (Q.S.Ali-Imran : 
156).

Penyesalan dalam hati bisa terjadi karena kelalaian, kurangnya ikhtiar, dan karena lemahnya keimanan kepada Allah SWT.Sebab,jika seseorang memiliki iman yang kuat, maka apapun yang terjadi dalam kehidupannya akan selalu diterima dengan hati yang ridha, karena dia yakin semua yang terjadi dimuka bumi ini berdasarkan ketentuan dan takdir Allah SWT.

4. Kemarahan

Sumber kemarahan berada di dalam hati, seorang muslim selalu dituntut supaya dapat mengendalikan kemarahannya, karena kemarahan selalu dipengaruhi oleh syetan, dan Allah sudah menegaskan supaya orang muslim jangan mengikuti langkahlangkah syetan, dan menjadikan syetan sebagai musuh yang nyata dalam kehidupan. Firman Allah SWT: "Dan dia menghilangkan kemarahan hati mereka (orang mukmin). Dan Allah menerima tobat orang yang Dia kehendaki. Allah maha mengetahui, maha bijaksana" (Q.S. At-taubah : 15).

6. Keraguan

"Sesungguhnya yang akan meminta izin kepadamu (Muhammad), hanyalah orangorang yang tidak beriman kepada Allah dan hari kemudian, dan hati mereka ragu, karena itu mereka selalu bimbang dalam keraguan" (Q.S. At-Taubah : 45).

Keraguan yang terjadi di dalam hati disebabkan kurangnya pemahaman kepada ayat-ayat Allah.Baik ayat qauliyah (AlQur'an) maupun ayat kauniyah (Alam semesta).Sehingga untuk memperkuat keimanan, manusia dituntut untuk memahami kedua ayat tersebut. Orang muslim dituntut untuk memahami kebesaran Allah melalui petunjuk Al-Qur'an dan merenungkan keindahan alam semesta sebagai bukti kekuasaan dan kebesarannya.

7. Kemunafikan

Kemunafikan adalah penyakit hati yang paling berbahaya, karena perkataan, perilaku, dan pengakuannya selalu bertentangan dengan hatinya. Orang yang dalam hatinya terkandung kemunafikan akan sulit menepati janjinya, sulit untuk berkata jujur, dan sulit untuk menjaga amanah orang lain. Firman Allah SWT:

"Maka Allah menanamkan kemunafikan dalam hati mereka sampai pada watu mereka menemuinya, karena mereka telah mengingkari janji yang telah mereka ingkarkan kepadanya dan (juga) karena mereka selalu berdusta" (Q.S. At-Taubah 77).

8. Kesombongan

"Ketika orang-orang yang kafir menanamkan kesombongan dalam hati mereka (yaitu) kesombongan jahiliyah, maka Allah menurunkan ketenangan kepada rasulnya, dan kepada orang-orang mukmin, dan (Allah) mewajibkan kepada mereka 
tetap taat menjalankan kalimat takwa, dan mereka lebih berhak dengan itu dan patut memilikinya. Dan Allah maha mengetahui segala sesuatu" (Q.S. Al-Fath : 26).

Kesombongan adalah salah satu penyakit hati yang sangat berbahaya, karena orang yang sombong akan memandang rendah semua yang ada di sekelilingnya, orang yang sombong juga akan menolak kebenaran yang ada dihadapannya. Bahkan rasulullah pernah bersabda dalam haditsnya: "Tidak akan masuk syurga seseorang yang di dalam hatinya terdapat kesombongan walaupun hanya sebesar biji sawi."(H.R. Muslim).

5. Persaan Takut

Rasa takut ada yang positif dan ada juga yang negatif, takut yang positif adalah ketakutannya berbuat maksiat kepada Allah, ketakutan ini akan mengahantarkan manusia kepada ketakwaan. Sementara ketakutan yang negatif adalah ketakutan yang dimasukkan Allah ke dalam hati orang-orang kafir, karena mereka menentang dan mempersekutukan Allah. Hal ini sesuai dengan firman Allah SWT:

"Akan kami masukkan rasa takut ke dalam hati orang-orang kafir, karena mereka mempersekutukan Allah dengan sesuatu yang Allah tidak menurunkan keterangan tentang
itu.Dan tempat kembali mereka ialah neraka. Dan itulah seburukburuk tempat tinggal (bagi orangorang zalim" (Q.S. Ali-Imran: 151).

\section{KESIMPULAN}

Berdasarkan fungsi, potensi, kandungan, sifat, karaktersitik dan kualitas qalbu yang disebut dalam AlQur'an, maka Qalbu mempunyai kedudukan yang sangat menentukan dalam sistem nafsani (kepribadian) manusia. Qalbulah yang menentukan dan menolak sesuatu, dan Qalbu pulalah yang memikul tanggung jawab atas apa yang diputuskan. Sehingga dengan demikan dapat diketahui bahwa Qalbu memiliki fungsi :

a. Qalbu merupakan bagian dari nafs yang bekerja memahami, mengolah, menampung realita disekelilingnya, dan memutuskan sesuatu.

b. Sesuai dengan potensinya, maka Qalbu merupakan kekuatan yang sangat dinamis, tetapi ia temperamental, fluktuatif, emosional dan berbolak-balik.

c. Untuk memecahkan masalahmasalah yang dihadapi, Qalbu bekerja dengan jaringan akal, namun kondisi Qalbu dan akal terkadang tidak optimal sehingga dimungkinkan untuk terkontaminasi oleh pengaruh syahwat (motif yang mengarah kepada hal-hal negatif).

Dalam kondisi demikian, Qalbu dan akal dapat melakukan helah mental, yaitu memandang sesuatu 
Anri Saputra, Mela Rospita, Vivik Shofiah : Qalbu Dalam Kajian Psikologi Islam DOI:10.24014/af.v18.i1.7154

dengan alasan-alasan yang dibuatnya, sehingga seakan-akan yang salah itu menjadi wajar.Untuk mengoreksi penyimpanganpenyimpangan Qalbu dan akal dilakukan oleh basyirah.

d. Qalbu hanya menampung hal-hal yang disadari dan keputusan Qalbu mengandung implikasi pahala dan dosa.

e. Hal-hal yang sudah dilupakan qalbu akan masuk ke dalam memori nafs, yang pada suatu saat dapat muncul dalam bentuk impian.

\section{DAFTAR PUSTAKA}

Al-Ghazali.1988. Ihya' 'ulum aldin.Kaherah : Dar al-Tauzi'.

Al-Qur'an. 2010. Syamil Qur'an Bukhara, Tajwid dan Terjemahnya.Bandung : PT. Sigma Examedia Arkanleema.

Attabik, A.\& Zuhdi. A. 1973. Kamus Kontemporer Arab-Indonesia. Jakarta:Yayasan

Penyelenggara

Penerjemahan al-Qur'an.

Baharuddin. 2007. Paradigma Psikologi Islam (Studi Tentang Elemen Psikologi dan Al-Qur'an).Yogyakarta : Psutaka Pelajar

Bastaman, H. D. 2005. Integrasi Psikologi dengan Islam Menuju Psikologi Islam.Yogyakarta : Pustaka Pelajar.
Corbin, H. 1998. Alone With The Alone. Unitet State Of America : Prenceton University Press.

Faridi,S. 1986. Inner Aspects of Faith. Kuala Lumpur : A.S. Noordeen.

Gawain,

$\mathrm{S}$. 2002. Meditation.Calipornia Nataraj Publishing.

Mubarok, A. 2002.Al-Irsyad An-Nafsiy Konseling Agama Teori dan Kasus.Jakarta : Bina Rena Pariwara.

Mujib, A. 2017.Teori Kepribadian Perspektif psikologi Islam.Jakarta : Rajawali Pers

Mukhlis \& Lestari, Y.I. 2011.Psikologi Islam.Pekanbaru : AlMujtahadah Press.

Sugiyono. 2012. Metode Penelitian Kuantitatif Kualitatif dan $R \& D$. Bandung: Alfabeta.

Sukanto. 1985. Nafisologi Sutau Pendekatan Alternatif Atas Psikologi.Jakarta : Integaritas Press.

Wibirama, S.2009. "Geliat Islam di Thailand,"

Wibiramahttp://wibirama.com/ 2009/02/23/s-wibirama-geliatislam-di-thailand/(diakses pada 18 Mei 2012).

Yunus, M. 1990. Kamus ArabIndonesia.Jakarta : Hidaya Karya Agung. 
Al-Fikra: Jurnal IImiah Keislaman, Vol. 18, No. 1, Januari - Juni, 2019 (43-51) DOI:10.24014/af.v18.i1.7154

Yusuf, Y. M. 2003. Corak Pemikiran

Kalam Tafsir Al-

Azhar.Jakarta : Penamadani. 